\author{
mgr Magda WIŚNIEWSKA-KUŹMA \\ Wydział Ekonomii i Zarządzania, Uniwersytet w Białymstoku \\ e-mail: m.wisniewska@uwb.edu.p1 \\ ORCID: 0000-0002-9076-7365
}

DOI: $10.15290 /$ oes.2018.04.94.15

\title{
STRUKTURA WYDATKÓW PUBLICZNYCH A POZIOM DOBROBYTU W WYBRANYCH KRAJACH
}

\begin{abstract}
Streszczenie
Cel - Celem opracowania jest wyodrębnienie modeli fiskalnych na podstawie struktury wydatków publicznych i porównanie ich pod względem poziomu dobrobytu społeczno-ekonomicznego.

Metodologia badania - Na podstawie głównych koncepcji dobrobytu wyłoniono cztery kategorie wydatków publicznych, które następnie wykorzystano do klasyfikacji modeli fiskalnych przy pomocy analizy skupień metodą aglomeracji na grupie 26 państw OECD. Do analizy porównawczej modeli zastosowano Indeks Dobrobytu, bazujący na konstrukcji miernika rozwoju społeczno-gospodarczego HDI.

Wynik - W strukturze wydatków publicznych zidentyfikowano cztery podstawowe kategorie wydatków: klasyczne, wspierające gospodarkę, inwestycje w kapitał ludzki i ochrona socjalna. Na ich podstawie wyodrębniono pięć modeli fiskalnych. Wyłoniony w toku analizy porównawczej model fiskalny o najwyższym poziomie Indeksu Dobrobytu opiera się na dominującym udziale wydatków socjalnych oraz minimalnym znaczeniu wydatków klasycznych i wspierających gospodarkę. Modele charakteryzujące się wysokim udziałem tych kategorii wydatków odznaczają się najniższym poziomem Indeksu Dobrobytu.
\end{abstract}

Słowa kluczowe: wydatki publiczne, struktura wydatków publicznych, dobrobyt, indeks dobrobytu

\section{STRUCTURE OF PUBLIC EXPENDITURE AND QUALITY OF LIFE IN SELECTED COUNTRIES}

\section{Summary}

Goal - The aim of the study is to distinguish fiscal models based on the structure of public expenditure and compare them in terms of the level of socio-economic quality of life.

Research methodology - Based on the main concepts of quality of life, four categories of public expenditure were selected, which were then used to classify fiscal models by cluster agglomeration analysis on a group of 26 OECD countries. A Quality of Life Index, based on the construction of a measure of social and economic development of HDI, was applied to the comparative analysis of the models.

Score - In the structure of public expenditure, four basic expenditure categories were identified: classic, supporting the economy, investments in human capital and social protection. Based on them, five fiscal models were identified. The fiscal model of the highest level of the Quality of Life Index, selected in the course of the comparative analysis, is based on the dominating share of social expenditures and the minimal importance of classical expenditures and supporting the economy. Models characterized by a high share of these categories of expenditures have achieved by the lowest level of the Quality of Life Index. 
Key words: public expenditure, structure of public expenditure, welfare, welfare index

JEL classification: E6, H5, I3

\section{Wstęp}

Koncepcja dobrobytu społeczno-ekonomicznego ewoluowała na przestrzeni wieków - począwszy od postrzegania tego pojęcia przez pryzmat bogactwa narodów, czy użyteczności, po szeroko rozumiana jakość życia, uwzględniająca nie tylko uwarunkowania ekonomiczne funkcjonowania człowieka i całego społeczeństwa, ale także psychologiczne, społeczne, polityczne etc. Współczesne podejście do dobrobytu bazuje na kilku istotnych koncepcjach: możliwości rozwojowych (wg A. Sena), możliwości ludzkich (wg Nussbauma), czy podstawowych potrzeb ludzkich (wg A.H. Maslowe, M. Max-Neef). Teorie te utożsamiają dobrobyt ze stanem zaspokojenia potrzeb bądź warunkami/możliwościami, w których następuje ich realizacja. W zagranicznej literaturze przedmiotu dobrobyt określany jest pojęciami takimi, jak: welfare, quality of life, well - being, wellness/holistic wellness. Należy jednak zaznaczyć, że nie są one tożsame. Najmniejszy zakres znaczeniowy posiada pojęcie welfare, ponieważ odnosi się jedynie do dobrobytu ekonomicznego, bazującego na teorii użyteczności dochodu. Szerszym pojęciem jest quality of life. Interpretowane jest jako jakość życia, na którą wpływają takie czynniki, jak np. poziom dochodu, majątek, konsumpcja, równość płci, stan środowiska, poczucie bezpieczeństwa, edukacja, jakość usług administracji publicznej, stan zdrowia, zabezpieczenie społeczne, aktywność zawodowa, życie rodzinne [Aksman, 2010, s. 139]. Well-being (dobrobyt ogólny) łączy obiektywne elementy jakości życia z subiektywnym uczuciem zadowolenia czy szczęścia. Rozumiany jest jako poziom satysfakcji z konsumpcji dóbr i usług. Najszerzej interpretowane jest pojęcie bolistic wellness łączące konwencjonalne wymiary dobrobytu (ekonomiczne, społeczne, psychologiczne, fizyczne) ze składnikami dotychczas pomijanymi, jak: rozwój intelektualny (ciekawość, chęć pogłębiania wiedzy, twórcza stymulacja), rozwój duchowy i świadomość ekologiczna.

W niniejszym artykule autorka podejmuje próbę wskazania dominującej koncepcji dobrobytu w wyodrębnionych na podstawie struktury wydatków publicznych modelach fiskalnych. Wybór podejścia do dobrobytu determinuje bowiem rodzaj i zakres aktywności państwa w kwestii wspomagania jego wzrostu. Kolejnym krokiem jest porównanie efektów stosowanej polityki poprzez ustalenie poziomu dobrobytu ogólnego dla wyłonionych w badaniu grup (reprezentujących podobny model fiskalizmu). Współcześnie popularnością cieszą się miary indeksowe dobrobytu o charakterze niepieniężnym, obliczane najczęściej jako średnie ważone wyników gospodarczych i społecznych z różnych dziedzin. W niniejszym artykule posłużono się syntetycznym indeksem dobrobytu, zbudowanym na wzór wskaźnika rozwoju społecznego HDI, uwzględniającym wysokość produktu krajowego per 
capita, zatrudnienia, dochodu rozporządzalnego gospodarstw domowych, innowacyjność kraju, zakres edukacji na poziomie uczelni wyższej i stan zdrowia obywateli.

\section{Metodyka}

Ze względu na wielowymiarowość dobrobytu społeczno-ekonomicznego ukazanie jednoznacznego wpływu wydatków publicznych na jego wysokość nastręcza wielu problemów badawczych. Na każdy z aspektów dobrobytu (bezpieczeństwo, edukacja, zdrowie, czas wolny, rozwój zawodowy, stan środowiska, dzietność etc.) oddziałuje wiele różnorodnych czynników, nie tylko o charakterze ekonomicznym. Istotny wpływ posiadaja także uwarunkowania kulturowe, historyczne, geograficzne itp. Na potrzeby niniejszego badania przyjęto uproszczony model, w którym skupiono się na wysokości udziałów poszczególnych kategorii wydatków publicznych, poszukując rozwiązań przynoszących najwyższe wskaźniki wybranych agregatów dobrobytu. Badanie przeprowadzono w pięciu etapach:

- wyodrębnienie czterech kategorii wydatków publicznych na podstawie ich funkcji, zgodnie z klasyfikacją CEFOG (klasyfikacja wydatków sektora instytucji rządowych i samorządowych według funkcji), doktrynalnych założeń fiskalizmu (liberalne funkcje klasyczne, welfaryzm) oraz poszczególnych koncepcji dobrobytu (funkcji maxmin, koncepcji możliwości rozwojowych A. Saya, dobrobytu postrzeganego przez pryzmat użyteczności dochodu i wzrostu gospodarczego),

- analiza danych statystycznych (pochodzacych z baz OECD i UNESCO) w zakresie wysokości wydatków publicznych ogółem w relacji do PKB oraz poszczególnych kategorii,

- $\quad$ analiza struktury wydatków publicznych - porównanie wysokości udziałów poszczególnych kategorii wydatków publicznych,

- $\quad$ klasyfikacja państw OECD pod względem struktury wydatków publicznych na podstawie analizy skupień metodą pełnego wiązania, przyjmując jako miarę odległości kwadratową odległość euklidesowa. Celem tego etapu badania było wyodrębnienie modeli fiskalizmu funkcjonujących w wybranych krajach,

- porównanie wyłonionych powyższą metodą modeli fiskalizmu na podstawie Indeksu Dobrobytu.

Badaniem objęto grupę państw OECD, w których znajdują się kraje Unii Europejskiej za wyjątkiem Cypru, Malty, Bułgarii, Rumunii, Chorwacji, ze względu na brak niezbędnych w analizie danych statystycznych wraz z dwoma krajami OECD reprezentującymi ekonomiczny model liberalny - Australia i USA. Zostały one uwzględnione w badaniu, aby przeanalizować stopień dystansu, dzielący europejskie modele fiskalne do modelu fiskalnego państw ujmowanych w literaturze przedmiotu jako przedstawicieli liberalnego modelu ekonomicznego.

W badaniu wyodrębniono cztery kategorie wydatków publicznych z wykorzystaniem klasyfikacji CEFOG. Zostały one przedstawione w tabeli 1. 
TABELA 1

Kategorie wydatków wyodrębnione na rzecz badania

\begin{tabular}{|c|c|c|c|}
\hline Kategoria & Opis & $\begin{array}{c}\text { Podstawowa } \\
\text { klasyfikacja } \\
\text { CEFOG } \\
\end{array}$ & Wyszczególnienie \\
\hline \multirow[t]{19}{*}{$\begin{array}{l}\text { wydatki } \\
\text { klasyczne }\end{array}$} & \multirow{19}{*}{$\begin{array}{l}\text { kategorie wydatków } \\
\text { związane z podsta- } \\
\text { wowymi funkcjami } \\
\text { państwa wymienianymi } \\
\text { w ekonomii klasycznej }\end{array}$} & \multirow[t]{8}{*}{$\begin{array}{l}\text { działalność } \\
\text { ogólnopaństwowa }\end{array}$} & $\begin{array}{l}\text { organy wykonawcze i ustawodawcze, } \\
\text { sprawy finansowe i skarbowe, sprawy } \\
\text { zagraniczne }\end{array}$ \\
\hline & & & polityka gospodarcza dla zagranicy \\
\hline & & & usługi ogólnopaństwowe \\
\hline & & & badania podstawowe \\
\hline & & & $\begin{array}{l}\text { prace badawczo-rozwojowe w tym } \\
\text { zakresie }\end{array}$ \\
\hline & & & transakcje długu publicznego \\
\hline & & & $\begin{array}{l}\text { transfery o charakterze ogólnym } \\
\text { między różnymi szczeblami sektora } \\
\text { instytucji rządowych i samorządowych }\end{array}$ \\
\hline & & & pozostała działalność \\
\hline & & \multirow[t]{5}{*}{ obrona narodowa } & obrona wojskowa \\
\hline & & & obrona cywilna \\
\hline & & & pomoc wojskowa dla zagranicy \\
\hline & & & $\begin{array}{l}\text { prace } \mathrm{B}+\mathrm{R} \text { w dziedzinie obrony } \\
\text { narodowej }\end{array}$ \\
\hline & & & pozostała działalność \\
\hline & & \multirow{6}{*}{$\begin{array}{l}\text { bezpieczeństwo } \\
\text { i porządek } \\
\text { publiczny }\end{array}$} & służby policyjne \\
\hline & & & służby pożarnicze \\
\hline & & & sądownictwo \\
\hline & & & więziennictwo \\
\hline & & & prace badawczo-rozwojowe \\
\hline & & & pozostałe działania \\
\hline \multirow[t]{8}{*}{$\begin{array}{l}\text { sprawy } \\
\text { gospodarcze }\end{array}$} & \multirow{8}{*}{$\begin{array}{l}\text { kategoria związana } \\
\text { z bezpośrednim } \\
\text { strumieniem środków } \\
\text { finansowych kiero- } \\
\text { wanych do określo- } \\
\text { nych gałęzi gospo- } \\
\text { darki, a zatem bazująca } \\
\text { na interwencjonistycz- } \\
\text { nych koncepcjach } \\
\text { dobrobytu }\end{array}$} & \multirow[t]{8}{*}{$\begin{array}{l}\text { sprawy gospo- } \\
\text { darcze }\end{array}$} & $\begin{array}{l}\text { sprawy ogólnogospodarcze, związane } \\
\text { z handlem i rynkiem pracy }\end{array}$ \\
\hline & & & $\begin{array}{l}\text { związane z rolnictwem, leśnictwem } \\
\text { i łowiectwem oraz rybactwem }\end{array}$ \\
\hline & & & $\begin{array}{l}\text { związane z gospodarką paliwowo- } \\
\text {-energetyczną }\end{array}$ \\
\hline & & & $\begin{array}{l}\text { związane z górnictwem, działalnością } \\
\text { produkcyjną i budownictwem }\end{array}$ \\
\hline & & & związane z transportem \\
\hline & & & związane z łącznością \\
\hline & & & pozostała działalność \\
\hline & & & prace badawczo-rozwojowe \\
\hline \multirow{3}{*}{$\begin{array}{l}\text { „inwestycje } \\
\text { w kapitał } \\
\text { ludzki” }\end{array}$} & \multirow{3}{*}{$\begin{array}{l}\text { wydatki wspierające } \\
\text { tworzenie warunków } \\
\text { do rozwoju jednostki; }\end{array}$} & \multirow{3}{*}{$\begin{array}{l}\text { ochrona } \\
\text { środowiska }\end{array}$} & gospodarka odpadami \\
\hline & & & gospodarka ściekami \\
\hline & & & redukcja zanieczyszczeń \\
\hline
\end{tabular}




\begin{tabular}{|c|c|c|c|}
\hline Kategoria & Opis & $\begin{array}{l}\text { Podstawowa } \\
\text { klasyfikacja } \\
\text { CEFOG }\end{array}$ & Wyszczególnienie \\
\hline & \multirow{29}{*}{$\begin{array}{l}\text { przyczyniają się do } \\
\text { tworzenia zespołu } \\
\text { możliwości (koncepcja } \\
\text { dobrobytu A. Sena), } \\
\text { którym jednostka } \\
\text { przypisuje własne rangi } \\
\text { i tworzy funkcję } \\
\text { użyteczności; wpływaja } \\
\text { pośrednio na dochody } \\
\text { pozwalając na } \\
\text { podwyższenie } \\
\text { możliwości człowieka, } \\
\text { jednakże sposób ich } \\
\text { wykorzystania i efekt } \\
\text { zależy jedynie od } \\
\text { jednostki; } \\
\text { koncepcję A. Sena } \\
\text { uzupełniaja } \\
\text { determinanty wymie- } \\
\text { nione przez M. Nuss- } \\
\text { baum: życie, zdrowie, } \\
\text { wykorzystywanie } \\
\text { zmysłów do kreacji, } \\
\text { emocje, zabawa, kont- } \\
\text { rola nad otoczeniem, } \\
\text { przynależność; } \\
\text { ich zapewnianie, jej } \\
\text { zdaniem, należy do } \\
\text { funkcji państwa }\end{array}$} & & $\begin{array}{l}\text { ochrona różnorodności biologicznej } \\
\text { i krajobrazu }\end{array}$ \\
\hline & & & prace badawczo-rozwojowe \\
\hline & & & pozostała działalność \\
\hline & & \multirow{6}{*}{$\begin{array}{l}\text { gospodarka } \\
\text { mieszkaniowa } \\
\text { i komunalna }\end{array}$} & rozwój gospodarki mieszkaniowej \\
\hline & & & rozwój gospodarki komunalnej \\
\hline & & & zaopatrzenie w wodę \\
\hline & & & oświetlenie ulic \\
\hline & & & prace badawczo-rozwojowe \\
\hline & & & pozostała działalność \\
\hline & & \multirow[t]{6}{*}{ zdrowie } & $\begin{array}{l}\text { produkty, przyrządy i urządzenia } \\
\text { medyczne }\end{array}$ \\
\hline & & & usługi ambulatoryjne \\
\hline & & & usługi szpitalne \\
\hline & & & $\begin{array}{l}\text { usługi w zakresie publicznej opieki } \\
\text { zdrowotnej }\end{array}$ \\
\hline & & & prace badawczo-rozwojowe \\
\hline & & & pozostała działalność \\
\hline & & \multirow{6}{*}{$\begin{array}{l}\text { rekreacja, kultura i } \\
\text { religia }\end{array}$} & usługi związane $z$ rekreacją i sportem \\
\hline & & & usługi związane z kulturą \\
\hline & & & $\begin{array}{l}\text { usługi radiowo-telewizyjne i } \\
\text { wydawnicze }\end{array}$ \\
\hline & & & $\begin{array}{l}\text { usługi związane z religią } \\
\text { i pozostałe usługi na rzecz } \\
\text { społeczności }\end{array}$ \\
\hline & & & prace badawczo-rozwojowe \\
\hline & & & pozostała działalność \\
\hline & & \multirow[t]{8}{*}{ edukacja } & $\begin{array}{l}\text { przedszkolna i w zakresie szkoły } \\
\text { podstawowej }\end{array}$ \\
\hline & & & w zakresie szkoły średniej \\
\hline & & & szkolnictwo policealne \\
\hline & & & szkolnictwo wyższe \\
\hline & & & $\begin{array}{l}\text { edukacja nie przyporządkowana do } \\
\text { konkretnego poziomu }\end{array}$ \\
\hline & & & $\begin{array}{l}\text { dodatkowe usługi na potrzeby } \\
\text { edukacji }\end{array}$ \\
\hline & & & prace badawczo-rozwojowe \\
\hline & & & pozostałe sprawy \\
\hline \multirow[t]{2}{*}{$\begin{array}{l}\text { ochrona } \\
\text { socjalna }\end{array}$} & \multirow{2}{*}{$\begin{array}{l}\text { wydatki zgodne } \\
\text { z funkcją dobrobytu } \\
\text { maxmin - podniesienie } \\
\text { ogólnego poziomu }\end{array}$} & \multirow[t]{2}{*}{ ochrona socjalna } & $\begin{array}{l}\text { świadczenia związane z chorobą } \\
\text { i niepełnosprawnością }\end{array}$ \\
\hline & & & $\begin{array}{l}\text { świadczenia związane ze starzeniem } \\
\text { się }\end{array}$ \\
\hline
\end{tabular}




\begin{tabular}{|c|c|c|c|}
\hline Kategoria & Opis & $\begin{array}{c}\text { Podstawowa } \\
\text { klasyfikacja } \\
\text { CEFOG }\end{array}$ & Wyszczególnienie \\
\hline & \multirow{6}{*}{$\begin{array}{l}\text { dobrobytu wymaga } \\
\text { podniesienia docho- } \\
\text { dów grupy społeczeń- } \\
\text { stwa w najgorszym } \\
\text { położeniu }\end{array}$} & & $\begin{array}{l}\text { świadczenia } \\
\text { z tytułu śmierci bliskiego }\end{array}$ \\
\hline & & & $\begin{array}{l}\text { świadczenia na rzecz rodzin } \\
\text { i dzieci }\end{array}$ \\
\hline & & & świadczenia $\mathrm{z}$ tytułu bezrobocia \\
\hline & & & zasiłki mieszkaniowe \\
\hline & & & $\begin{array}{l}\text { świadczenia dla osób zagrożonych } \\
\text { wykluczeniem społecznym, wcześniej } \\
\text { niesklasyfikowane }\end{array}$ \\
\hline & & & prace badawczo-rozwojowe \\
\hline
\end{tabular}

Źródło: opracowanie własne na podstawie: [OECD, 2011].

Indeks Dobrobytu skonstruowano na podstawie następujących wskaźników: PKB per capita, stopy zatrudnienia, wskaźnika liczby patentów na 100 tys. mieszkańców, wskaźnika skolaryzacji i oczekiwanej długości życia. PKB per capita jest podstawowym czynnikiem oddziałującym na dobrobyt, według przedstawicieli dochodowej koncepcji dobrobytu. Ukazuje wartość produkcji dóbr i usług w kraju, zmniejszoną o wartość produktów zużytych do tego procesu [Machowska-Ochrój, 2013, s. 13]. Wskaźnik ten nie obrazuje rzeczywistych efektów produkcji (część wytworzonego produktu nie służy zwiększaniu dobrobytu, np. degradacja środowiska, wzrost globalnych nierówności), a także nie zawiera dużej części aktywności człowieka, zwiększającej poziom dobrobytu zarówno poszczególnych jednostek, jak i całego społeczeństwa [Jackson, 2015]. Badanie Easterlina wykazało, że wysokiemu wzrostowi PKB per capita nie towarzyszy zwiększanie poziomu dobrobytu w długich przedziałach czasowych (Paradoks Easterlina) [Fender i in., 2011, s. 2]. Z kolei wyniki badań Stephenson'a i Wolfers'a wskazały na istnienie związku między wzrostem PKB per capita, a podnoszeniem dobrobytu - wyższy poziom PKB per capita umożliwia zaspokajanie potrzeb społeczeństwa, jednakże tego nie gwarantuje [Szopa, 2012, s. 30]. Z tego względu Indeks Dobrobytu uzupełniono o wskaźniki odzwierciedlające jakość życia społeczeństwa:

1. oczekiwana długość życia (przewidywana średnia długość życia w chwili narodzin, przy założeniu niezmienności aktualnych wskaźników zgonów) [www 1] jako wskaźnik zdrowia, jednego z najważniejszych czynników oddziałujących na długość i jakość życia człowieka. Biorąc pod uwage międzynarodowe statystyki WHO można zaobserwować, że w skali globalnej wyższy poziom PKB per capita przekłada się na wyższą oczekiwaną długość życia (państwa o wysokiej stopie ubóstwa - około 50-60 lat, a kraje rozwinięte - 70-85). Jednakże, biorąc pod uwage jedynie państwa rozwinięte zależność ta nie występuje;

2. wskaźnik skolaryzacji na poziomie szkoły wyższej (liczba uczniów jako odsetek oficjalnej populacji w wieku szkolnym, odpowiadającym temu samemu poziomowi kształcenia, wskaźnik powyżej 100\% - uwzględnienie 
słuchaczy w wieku przedemerytalnym i poniżej wymaganego wieku ze względu na wczesne lub późne uczestnictwo w systemie edukacji, także nieuzyskane promocji) [www 2]. Jest to istotna determinanta dobrobytu ogólnego, bowiem prowadzi do zwiększenia dochodów, produktywności, innowacyjności, postępu technicznego, technologicznego, a co za tym idzie do wzrostu jakości życia. Z perspektywy jednostki waga tego czynnika w kształtowaniu dobrobytu jest niższa niż z perspektywy całego społeczeństwa (wyżej oceniane jest bezpieczeństwo, dochód, konsumpcja etc.);

3. liczba patentów (Triada - zestaw patentów złożonych w trzech głównych urzędach patentowych: Europejskim Urzędzie Patentowym EPO, Japońskim Urzędzie Patentowym JPO i Urzędzie Patentów i Znaków Towarowych Stanów Zjednoczonych USPTO; przypisane sa państwu zamieszkania wynalazcy i według daty pierwszej rejestracji patentu) [www 3] na 100 tys. mieszkańców, jako miernik innowacyjności społeczeństwa. Wskaźnik ukazuje efekty działań edukacyjnych w wymiernej postaci produktów/rozwiązań wpływających na produktywność. Przyczynia się nie tylko do zwiększenia dochodów, ale i wzrostu jakości życia człowieka: długości jego życia, czasu wolnego, bezpieczeństwa etc.;

4. dochód rozporządzalny gospodarstw domowych [www 4] - suma wynagrodzeń z tytułu świadczenia pracy, dochodu z pracy na własny rachunek, z tytułu własności, transferów bieżących netto i świadczeń społecznych, pomniejszone o składki na ubezpieczenie społeczne i podatki - dochód stanowił podstawowy czynnik dobrobytu na przestrzeni wieków. Ta determinanta pozwala bowiem zaspokajać potrzeby człowieka, a wysokość dochodu wpływa w dużym stopniu na odczuwalną jakość życia;

5. stopa zatrudnienia (stosunek liczby pracujących do populacji w wieku produkcyjnym) [www 5] - miernik aktywności zawodowej, posiadającej wpływ na dobrobyt jednostki jako źródło dochodu i satysfakcji z samorealizacji oraz na dobrobyt ogólny wskutek pobudzania wzrostu produktu krajowego. Jest to czynnik oddziałujący na subiektywną ocenę jakości życia. Wiąże się bowiem z determinantami dobrobytu wskazanymi przez Nasbaum, takimi jak: poczucie przynależności, utrzymywanie kontaktów społecznych, wyrażanie tożsamości. Może być także postrzegany jako koszt deprecjacji kapitału ludzkiego, jeżeli dochodzi do nadużyć czy wypaczeń: zaniżone wynagrodzenie nie pozwalające na realizację podstawowych potrzeb, dyskryminacja na rynku pracy, zbyt wysoki wymiar pracy, niebezpieczne warunki pracy.

Do budowy Indeksu Dobrobytu wykorzystano konstrukcję wskaźnika HDI, czyli syntetycznego miernika opisującego poziom rozwoju społeczno-gospodarczego państw w odniesieniu do pozostałych. Najpierw ustalono wartości progowe: maksimum i minimum na podstawie danych z 2016 r. Następnie obliczono poszczególne podindeksy na podstawie następującego wzoru [Dąbrowa, 2011, s. 76]:

gdzie:

$$
\mathrm{I}=\left(\mathrm{X}_{\mathrm{akt}}-\mathrm{X}_{\min }\right) /\left(\mathrm{X}_{\max }-\mathrm{X}_{\mathrm{min}}\right) \text {, }
$$


$\mathrm{X}_{\text {akt }}$ - wartość aktualna,

$\mathrm{X}_{\max }$ - progowa wartość maksymalna,

$\mathrm{X}_{\min }$ - progowa wartość minimalna.

Indeks Dobrobytu wyznaczano na podstawie średniej arytmetycznej indeksów: PKB per capita, zatrudnienie, liczba patentów na 100 tys. mieszkańców, dochód rozporządzalny gospodarstw domowych, skolaryzacja, oczekiwana długość życia.

\section{Poziom dobrobytu w wyodrębnionych na podstawie struktury wydatków publicznych modelach fiskalnych}

Podstawowym argumentem zwiększania wydatków publicznych jest podnoszenie poziomu dobrobytu społeczeństwa. H. Dalton i A. Pigou na początku XX wieku zwrócili uwage na poziom strat $\mathrm{w}$ dobrobycie społecznym na skutek nierównego podziału bogactwa w społeczeństwie. Zdaniem A. Pigou stabilny wzrost i równy podział dochodu narodowego zbliża społeczeństwo do osiagnięcia optimum Pareto. Narzędziem gwarantującym sprawiedliwy podział bogactwa miała być odpowiednia polityka fiskalna. Wraz z H. Daltonem sformułował koncepcję transferów dochodów w obrębie społeczeństwa w celu zmniejszenia nierówności społecznych - od osób bardziej zamożnych do żyjących w ubóstwie. Zgodnie z warunkiem transferu Pigou-Dalton, każdy transfer dochodu, wyrównujący poziom dochodów, prowadzi do redukcji nierówności społecznych [Atkinson, Brandolini, 2014, s. 8]. Rozpatrywanie dobrobytu społecznego przez pryzmat niwelowania nierówności społecznych i stwarzania równych szans rozwojowych zostało zaadaptowane przez przedstawicieli interwencjonizmu państwowego na rzecz argumentowania zwiększania jego zakresu. Wzrost fiskalizmu jest przez nich postrzegany jako niezbędne działania podnoszące poziom dobrobytu społeczno-ekonomicznego zgodnie $z$ funkcja dobrobytu J. Rawlsa. Funkcja określana jako maxmin, zakłada mierzenie dobrobytu ogólnego jako równego dobrobytowi osoby lub grupy społecznej posiadającej najniższą użyteczność dochodu. Wzrost dochodu tej grupy skutkuje podniesieniem ogólnego poziomu dobrobytu [Biernacki, 2006, s. 119]. Aktywna działalność państwa w kreowaniu i podnoszeniu dobrobytu obywateli przejawia się w szerokim katalogu wydatków publicznych i ich wysokości mierzonej stosunkiem do produktu krajowego. Większość z państw rozwiniętych cechuje się wysokim zakresem ingerencji w funkcjonowanie gospodarki i społeczeństwa, oferując bezpośrednio szeroką gamę usług, wpływając na decyzje alokacyjne i dokonując redystrybucji dochodów, posiłkując się argumentem niesprawności rynku i obowiązku stymulacji wzrostu gospodarczego. Krytycy interwencjonizmu wskazuja jednak na następujące koszty wysokich wydatków publicznych: pozyskania źródeł ich finansowania, alokacji (w stosunku do sektora prywatnego niższa jakość oferowanych usług i niższy zwrot z inwestycji), dostosowania się sektora prywatnego do warunków inwestycyjnych stwarzanych przez sektor prywatny, behawioralny koszt dotacji (zmiany decyzji inwestycyjnych), koszt społeczny świadczeń socjalnych, zmiany wydajności działań 
inwestycyjnych (zniechęcanie do oszczędności) i stagnacji (hamowanie innowacji) [Mitchell, 2005, s. 4-5]. Przeprowadzone przez S. Fölstera i M. Henreksona [1999, s. 337-358] badanie, wykazało negatywny wpływ zbyt wysokich wydatków publicznych na tempo wzrostu realnego PKB per capita. Wzrost tempa zmian wydatków publicznych o $10 \%$, ich zdaniem, prowadzi do spadku dynamiki wzrostu PKB o 0,70,8 p.p. [Fölster, Henrekson, 2001, s. 1501-1520]. Z kolei według P. Hanssona i M. Henreksona wzrost całkowitych wydatków publicznych o 10 p.p. zmniejsza wzrost stopy wzrostu wskaźnika produktywności o $0,92 \%$ rocznie. Zaś B. Abrams [1999, s. 3-4] wykazał, że wzrost wydatków publicznych o 1\% PKB skutkuje zwiększeniem stopy bezrobocia o 0,36 p.p. A. Alesina, S. Ardagna, R. Perotti i F. Schiantarelli [1999, s. 4] stwierdzili, że redukcja o 1 p.p. stopy wzrostu wydatków publicznych jako \% PKB będzie skutkować wzrostem o 0,16 p.p. inwestycji jako $\% \mathrm{PKB}$ w pierwszym roku, w drugim roku skumulowany wzrost będzie wyższy o 0,5 a po pięciu latach o 0,8. Badania Międzynarodowego Funduszu Walutowego wykazały, że kraje o niższym zakresie wydatków publicznych uzyskują lepsze wyniki w kwestii poziomu szarej strefy, liczby patentów, stopy bezrobocia [Tanzi, Shuknecht, 1996]. Wyznaczenie optymalnego progu wydatków publicznych uniwersalnego dla wielu krajów jest niemożliwe, bowiem należy uwzględnić warunki gospodarcze danego kraju, jego uwarunkowania kulturowe, historyczne i geopolityczne, a także społeczne oczekiwania. Na przykładzie USA badacze A.E. Paden [1991, s. 153-173] i G. Karras [1996, s. 2] wyznaczyli optymalny poziom wydatków na poziomie $20 \%$ i $23 \%( \pm 2 \%)$ PKB.

W wybranych do badania państwach wskaźnik poziomu wydatków publicznych w relacji do PKB znajduje się w przedziale $<28,8-57,1 \%>$. Najniższy poziom wydatków publicznych charakteryzuje takie kraje, jak: Irlandia $(28,8 \%)$, Litwa $(34,9 \%)$, USA $(37,6 \%)$ i Lotwa $(38,5 \%)$. Z kolei najwyższy poziom wydatków publicznych w relacji do PKB cechuje kraje modelu opiekuńczego (Finlandia 57,1\%, Dania $54,8 \%$ ), kontynentalnego (Francja 56,6\%, Belgia 53,8\%) i śródziemnomorskiego (Grecja 53,8\%, Włochy 50,2\%).

W niniejszym artykule przyjęto założenie, że zakres ingerencji państwa w funkcjonowanie gospodarki i podnoszenie dobrobytu ogólnego, ukazuje nie sama wysokość wydatków publicznych, a poziom poszczególnych ich kategorii w strukturze wydatków publicznych. W wybranych krajach OECD jest ona silnie zróżnicowana, jednakże zachowane sa pewne cechy wspólne, jak: dominacja wydatków związanych z poprawa dobrobytu społeczeństwa, czyli tzw. ,inwestycjami w kapitał ludzki $<23,7 ; 45,6 \%>$ i ochroną socjalną $<28,18 \% ; 49,4 \%>$. Udział wydatków na wsparcie gospodarki waha się w przedziale $<6,2 \% ; 15,1 \%\rangle$. Wydatki klasyczne, wynikające z podstawowych funkcji państwa, jak zapewnienie bezpieczeństwa i porządku publicznego, obrony suwerenności i państwowości oraz obsługi administracyjnej, stanowią około $20 \%$ ogółu wydatków. 
RYSUNEK 1

Struktura wydatków publicznych w 2016 r. w wybranych krajach

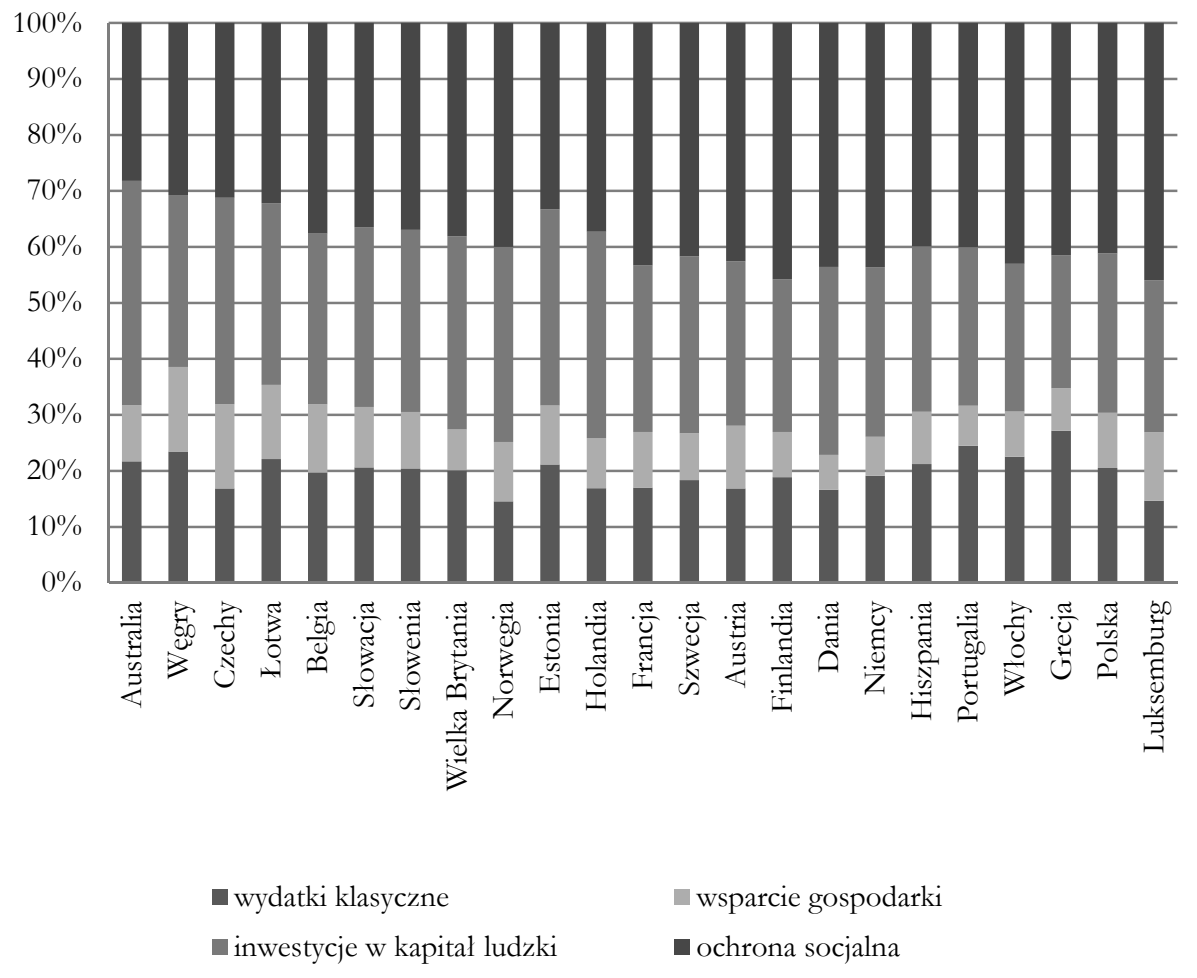

Źródło: opracowanie własne.

Realizacja celu niniejszego opracowania, jakim jest wyodrębnienie modeli fiskalnych na podstawie struktury wydatków publicznych, nastąpiła w oparciu o analizę danych przy pomocy algorytmu aglomeracji. Analiza dobrobytu została przeprowadzona na pięciu skupieniach (odrzucono w analizie USA, które zostało powiązane $z$ innymi państwami na dalekim etapie wiązania). Do ich wyłonienia posłużył wykres przebiegu aglomeracji, pokazujący odległości między skupieniami w momencie ich łączenia. Autorka dokonała odcięcia skupień w miejscu pierwszego skokowego wzrostu odległości wiązania (kwadrat odległości euklidesowej 180). 
RYSUNEK 2

\section{Diagram drzewa $\mathrm{i}$ wykres przebiegu aglomeracji wykonany}

\section{w programie Statistica}
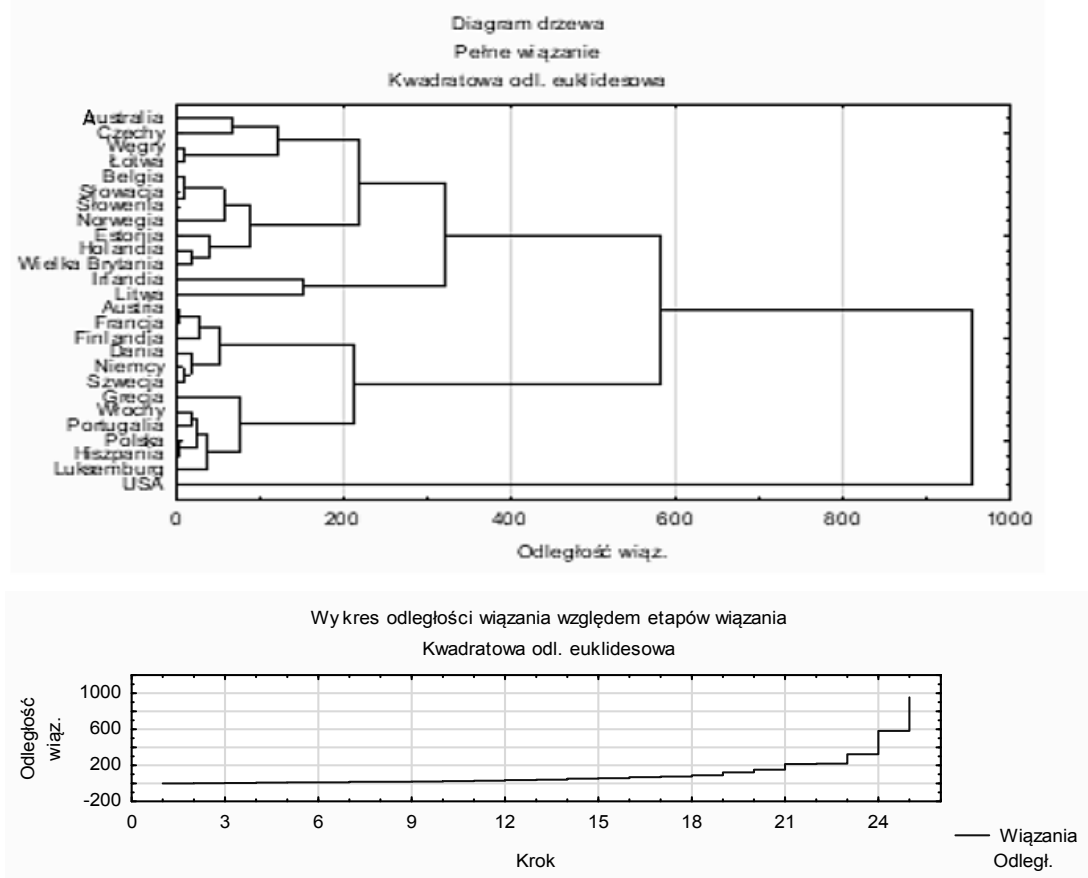

Źródło: opracowanie własne.

W odniesieniu do przedstawionych wcześniej koncepcji dobrobytu i dominujących kategorii wydatków w państwach przyporządkowanych do danego skupienia, autorka opracowała następujące modele dobrobytu: „możliwości rozwojowych”, „zrównoważonego wsparcia”, „ochrony socjalnej”, „administracyjno-socjalny” i „liberalny”. Tabela 2 zawiera średni poziom wyodrębnionych kategorii wydatków w modelach fiskalnych oraz wariancję z próby, ukazującą zróżnicowanie udziałów poszczególnych kategorii wydatków wśród państw przyporządkowanych do danego modelu fiskalnego. 
TABELA 2

Średnia arytmetyczna i wariancja z próby udziałów poszczególnych kategorii wydatków w strukturze wydatków publicznych modeli fiskalizmu

\begin{tabular}{|c|c|c|c|c|c|}
\hline & $\begin{array}{c}\text { Model } \\
\text { „możliwości } \\
\text { rozwojowych” }\end{array}$ & $\begin{array}{c}\text { Model } \\
\text { „zrównoważonego } \\
\text { wsparcia" }\end{array}$ & $\begin{array}{l}\text { Model } \\
\text { „ochrony } \\
\text { socjalnej” }\end{array}$ & $\begin{array}{c}\text { Model } \\
\text {,administracyjno- } \\
\text { socjalny" }\end{array}$ & $\begin{array}{c}\text { Model } \\
\text { „liberalny” }\end{array}$ \\
\hline Państwa & $\begin{array}{l}\text { Australia, } \\
\text { Czechy, Wegry, } \\
\text { Lotwa }\end{array}$ & \begin{tabular}{|l|} 
Belgia, Słowacja, \\
Słowenia, \\
Norwegia, Estonia, \\
Holandia, Wielka \\
Brytania
\end{tabular} & $\begin{array}{l}\text { Austria, } \\
\text { Francja, } \\
\text { Finlandia, } \\
\text { Dania, } \\
\text { Niemcy, } \\
\text { Szwecja } \\
\end{array}$ & $\begin{array}{l}\text { Grecja, Włochy, } \\
\text { Portugalia, Polska, } \\
\text { Hiszpania, } \\
\text { Luksemburg }\end{array}$ & $\begin{array}{l}\text { Irlandia, } \\
\text { Litwa }\end{array}$ \\
\hline $\begin{array}{l}\text { Wydatki } \\
\text { klasyczne }\end{array}$ & $\begin{array}{l}21,04 \\
(8,25) \\
\end{array}$ & $\begin{array}{l}19,08 \\
(5,87) \\
\end{array}$ & $\begin{array}{l}17,81 \\
(1,23) \\
\end{array}$ & $\begin{array}{c}21,93 \\
(14,98) \\
\end{array}$ & $\begin{array}{l}19,63 \\
(2,51) \\
\end{array}$ \\
\hline $\begin{array}{l}\text { Wsparcie } \\
\text { gospodarki }\end{array}$ & $\begin{array}{l}13,35 \\
(5,68) \\
\end{array}$ & $\begin{array}{l}10,06 \\
(2,41) \\
\end{array}$ & $\begin{array}{c}8,47 \\
(3,37) \\
\end{array}$ & $\begin{array}{c}9,19 \\
(4,89)\end{array}$ & $\begin{array}{c}8,63 \\
(0,04) \\
\end{array}$ \\
\hline $\begin{array}{l}\text { Inwestycje } \\
\text { w kapitał } \\
\text { ludzki }\end{array}$ & $\begin{array}{c}35,02 \\
(18,02)\end{array}$ & $\begin{array}{l}33,76 \\
(4,57)\end{array}$ & $\begin{array}{c}30,03 \\
(4,5)\end{array}$ & $\begin{array}{l}27,57 \\
(4,92)\end{array}$ & $\begin{array}{c}41,5 \\
(33,42)\end{array}$ \\
\hline $\begin{array}{l}\text { Ochrona } \\
\text { socjalna }\end{array}$ & $\begin{array}{c}30,57 \\
(2,9)\end{array}$ & $\begin{array}{c}37,1 \\
(4,09)\end{array}$ & $\begin{array}{l}43,41 \\
(1,87)\end{array}$ & $\begin{array}{c}42,45 \\
(12,58)\end{array}$ & $\begin{array}{l}34,54 \\
(6,48)\end{array}$ \\
\hline
\end{tabular}

Źródło: opracowanie własne.

Model „możliwości rozwojowych” charakteryzuje się najwyższym spośród innych modeli udziałem wydatków na cele gospodarcze i wysokim udziałem inwestycji w kapitał ludzki. Zdaniem A. Sena, zadaniem państwa jest stworzenie odpowiednich warunków do rozwoju ,zdolności do funkcjonowania”, czyli realnych możliwości do kreowania własnego dobrobytu przez obywateli. Stąd wysoki udział wydatków na inwestycje w kapitał ludzki, stanowiących nie bezpośrednie wsparcie finansowe obywateli, ale pośrednio oddziałujące na dobrobyt (pobudzanie aktywności zawodowej, zwiększania produktywności, ogólna jakość kapitału ludzkiego zdrowie, kompetencje, wiedza) autorka interpretuje jako zgodny z teorią dobrobytu A. Sena. Wspierane są bowiem wówczas obszary funkcjonowania człowieka zwiększające jego możliwości uzyskania czy podniesienia dochodów: wzrost wiedzy, kompetencji, zdrowia etc. Dotychczasowe badania potwierdzają istotny wpływ wydatków na edukację i opiekę zdrowotną na determinanty dobrobytu: nierówności dochodowe [Paternoso i in., 2007, s. 47-48], stan zdrowia [Novingnon i in., 2012], PKB per capita [Veugelers, van der Ploeg, 2008] i produktywność [Fuente, Jimeno, 2005]. W modelu „możliwości rozwojowych" państwo tworzy warunki do samodzielnego zwiększania dobrobytu przez jednostkę, co potwierdza najniższy udział wydatków na ochronę socjalną w klasyfikacji. Jednakże wysoki udział wydatków zorientowanych na stymulowanie gospodarki wskazuje, że państwo, w wysokim stopniu, ingeruje w jej funkcjonowanie. Ten model fiskalizmu można określić jako stymulacyjny, w którym państwo przez aktywne działania dąży do zwiększenia dobrobytu zgodnie z założonymi celami. Wyrazem koncepcji dobrobytu A. Sena, jednakże o niższym stopniu interwencjonizmu, jest model „liberalny”, z najwyższym 
spośród pozostałych modeli udziałem wydatków na inwestycje w kapitał ludzki. Cechuje się także jednym z niższych udziałów wydatków klasycznych, stymulujących gospodarkę oraz socjalnych. Model „zrównoważonego wsparcia” odznacza się relatywnie wysokim udziałem wydatków na ochronę socjalną i wydatków na inwestycje w kapitał ludzki. Pozostałe kategorie wydatków (klasyczne i wsparcie gospodarki) nie wyróżniają się znacząco na tle pozostałych grup - ich poziom kształtuje się blisko wartości środkowych dla wyodrębnionych modeli. Taka struktura wydatków świadczy o realizacji przez państwo koncepcji dobrobytu A. Sena (stwarzanie równych możliwości) w połączeniu z funkcją maxmin (podniesienie dobrobytu najuboższych prowadzi do wzrostu poziomu ogólnego dobrobytu).

TABELA 3

Indeks Dobrobytu i jego składowe - porównanie modeli fiskalizmu na podstawie średniej arytmetycznej i wariancji z próby

\begin{tabular}{|c|c|c|c|c|c|c|c|c|c|c|}
\hline & \multicolumn{2}{|c|}{$\begin{array}{c}\text { Model } \\
\text { „możliwości } \\
\text { rozwojowych” }\end{array}$} & \multicolumn{2}{|c|}{$\begin{array}{c}\text { Model } \\
\text { „zrównoważonego } \\
\text { wsparcia" }\end{array}$} & \multicolumn{2}{|c|}{$\begin{array}{c}\text { Model } \\
\text { „ochrony } \\
\text { socjalnej” }\end{array}$} & \multicolumn{2}{|c|}{$\begin{array}{c}\text { Model } \\
\text {,administracyjno- } \\
\text { socjalny” }\end{array}$} & \multicolumn{2}{|c|}{$\begin{array}{c}\text { Model } \\
\text { „liberalny” }\end{array}$} \\
\hline & $\mathrm{m}$ & $\mathbf{S}^{2}$ & $\mathrm{~m}$ & $\mathbf{S}^{2}$ & $\mathrm{~m}$ & $\mathbf{S}^{2}$ & $\mathrm{~m}$ & $\mathbf{S}^{2}$ & m & $\mathbf{S}^{2}$ \\
\hline PKB per capita & 0,1 & 0,02 & 0,21 & 0,02 & 0,28 & 0,002 & 0,23 & 0,14 & 0,32 & 0,14 \\
\hline Zatrudnienie & 0,74 & 0,01 & 0,73 & 0,04 & 0,85 & 0,02 & 0,36 & 0,05 & 0,66 & 0,007 \\
\hline Skolaryzacja & 0,55 & 0,09 & 0,48 & 0,01 & 0,52 & 0,01 & 0,49 & 0,1 & 0,51 & 0,002 \\
\hline $\begin{array}{l}\text { Oczekiwana } \\
\text { długość życia }\end{array}$ & 0,39 & 0,16 & 0,66 & 0,05 & 0,8 & 0,005 & 0,75 & 0,05 & 0,41 & 0,32 \\
\hline $\begin{array}{l}\text { Liczba } \\
\text { patentów na } \\
100 \text { tys. osób }\end{array}$ & 0,06 & 0,007 & 0,34 & 0,12 & 0,77 & 0,02 & 0,13 & 0,04 & 0,16 & 0,04 \\
\hline $\begin{array}{l}\text { Dochód } \\
\text { rozporządzalny } \\
\text { gospodarstw } \\
\text { domowych }\end{array}$ & 0,25 & 0,13 & 0,43 & 0,07 & 0,66 & 0,009 & 0,36 & 0,11 & 0,27 & 0,01 \\
\hline Ogółem & 0,35 & 0,07 & 0,47 & 0,05 & 0,65 & 0,01 & 0,39 & 0,09 & 0,39 & 0,09 \\
\hline
\end{tabular}

Źródło: opracowanie własne.

Najniższy udział wydatków na inwestycje w kapital ludzki wykazuja państwa wchodzące w skład modelu ,administracyjno-socjalnego”. Wysoki udział wydatków klasycznych świadczy o rozbudowanym aparacie administracyjnym (w przeciwieństwie do pozostałych modeli w tej kategorii wydatków dominuja koszty administracji, a nie środki na obronność i zapewnienie porządku publicznego), co przy niskim udziale wydatków wspierających gospodarkę i najniższym udziale wydatków na inwestycje w kapitał ludzki rodzi pytania o racjonalność wydatkowania dochodów podatkowych i ich efektywność. Podsumowując, struktura wydatków w modelu ,administracyjno-socjalnym" skupia się na kreowaniu dobrobytu zgodnie z koncepcją dochodowa przez bezpośrednie transfery środków finansowych na rzecz gospodarstw domowych (zwiększanie dochodów ludności), a nie tworzeniu warunków do samodzielnego kształtowania dobrobytu przez jednostkę według koncepcji 
A. Sena czy współczesnych koncepcji quality of life. Zbliżoną strukturą wydatków charakteryzuje się model „ochrony socjalnej”. Wykazuje najwyższy udział wydatków na cele socjalne, przy najniższych inwestycjach w gospodarkę i niskim udziale wydatków na cel inwestycji w kapitał ludzki. Jednakże, w przeciwieństwie do modelu „administracyjno-socjalnego”, zwiększone transfery na rzecz społeczeństwa odbywają się kosztem wydatków związanych z administracją, obronnością i porządkiem publicznym. Model fiskalny realizuje zatem koncepcję dochodową dobrobytu, jednakże cechuje się wyższą sprawnością aparatu administracyjnego. Wyodrębnienie modeli fiskalizmu pozwala postawić kolejne pytanie badawcze: który z modeli cechuje się wyższym poziomem dobrobytu? Odpowiedź na to pytanie po części wskaże również słuszność reprezentowanej przez model fiskalny koncepcji dobrobytu: dochodowej maxmin (zwiększenie dochodów ludności bez ingerencji w sposób ich wydatkowania) czy „możliwości rozwojowych” (stymulowanie podnoszenia dobrobytu przez jednostkę przez stworzenie kompleksowego systemu wsparcia, zgodnie z przyjętymi założeniami polityki gospodarczej).

RYSUNEK 3

\section{Wskaźniki Indeksu Dobrobytu w krajach zaklasyfikowanych do modelu „możliwości rozwojowych'}

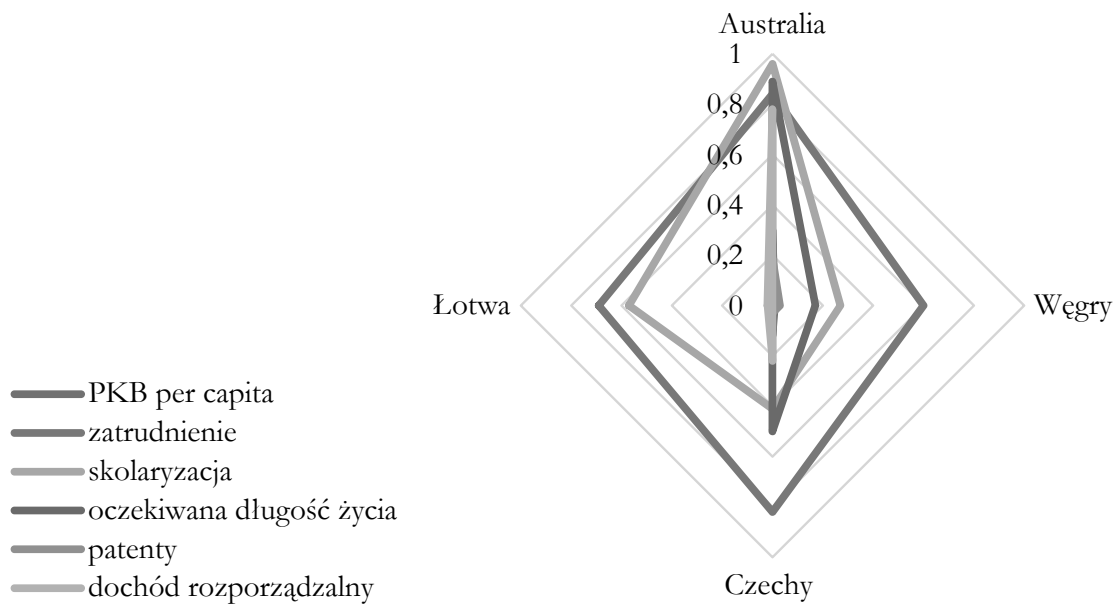

Źródło: opracowanie własne.

Model „możliwości rozwojowych” uzyskał najniższy poziom Indeksu Dobrobytu $(0,35)$. Najwyższe wskaźniki w tym modelu osiagnnięto w kategorii zatrudnienie (średnia 0,74) i skolaryzacja $(0,55)$. W przypadku wskaźnika zatrudnienia nie wystapiły znaczace odchylenia od średniej (wariancja z próbki 0,01 ), jednakże we wskaźniku skolaryzacja dystans dzielący państwa w tej kategorii jest wysoki: najwyższy wskaźnik występuje w Australii (wskaźnik 0,96), a najniższy w Węgrzech $(0,27)$. Z kolei najsłabszy spośród pięciu modeli wynik uzyskał w kategorii PKB per capita $(0,1)$, oczekiwana długość życia $(0,06)$, liczba patentów na 100 tys. osób $(0,06)$ 
i dochód rozporządzalny gospodarstw domowych $(0,25)$. W modelu najwyższy poziom wskaźników uzyskała Australia. Łotwa i Węgry, w wielu kryteriach, uzyskały najniższe spośród badanych państw wyniki (za wyjątkiem wskaźnika zatrudnienie). Zróżnicowanie gospodarek wchodzących w skład modelu jest na porównywalnym poziomie $(0,07)$ jak w pozostałych (oprócz modelu „ochrony socjalnej”).

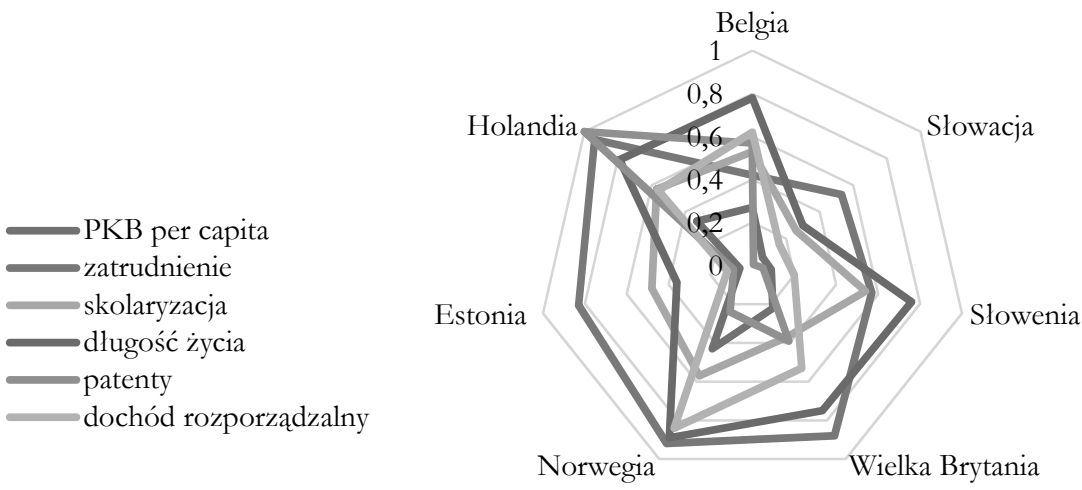

\section{Wskaźniki Indeksu Dobrobytu w krajach zaklasyfikowanych do modelu „zrównoważonego wsparcia”}

Źródło: opracowanie własne.

Model „zrównoważonego wsparcia” znajduje się na drugim miejscu pod względem wysokości indeksu dobrobytu $(0,47)$. Jego stopień zróżnicowania jest porównywalny z pozostałymi modelami (za wyjątkiem modelu „ochrony socjalnej”). Uzyskał stosunkowo wysokie wyniki w kategorii innowacyjności i dochodów gospodarstw domowych (na drugim miejscu za modelem „ochrony socjalnej”), a spośród wszystkich modeli najniższe noty we wskaźniku skolaryzacja $(0,47)$. W pozostałych składowych Indeksu plasuje się na trzecim miejscu. Najwyższe różnice występują w przypadku wskaźnika innowacyjności (wariancja z próby 0,12 ) i dochodu $(0,07)$. Najwyższe dochody uzyskuja mieszkańcy Norwegii, Belgii i Wielkiej Brytanii, z kolei najniższe - Słowacja, Słowenia i Estonia. Wśród liderów innowacyjności znajduje się Holandia i Belgia, zaś Słowacja, Słowenia i Estonia zajmuja jedne z ostatnich miejsc pod względem liczby patentów w całej badanej grupie. 


\section{RYSUNEK 5}

\section{Wskaźniki Indeksu Dobrobytu w krajach zaklasyfikowanych do modelu „ochrony socjalnej”}

PKB per capita

zatrudnienie

skolaryzacja

długość życia

patenty

dochód rozporządzalny

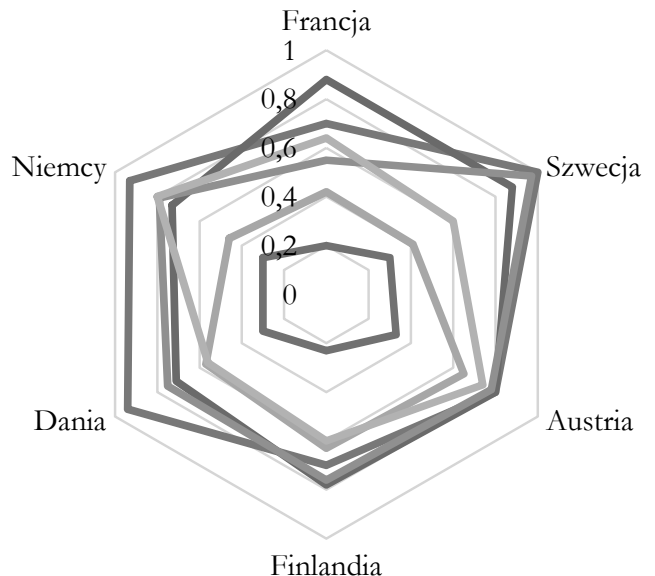

Finlandia

Źródło: opracowanie własne.

Model „ochrony socjalnej” uzyskał najwyższy poziom Indeksu Dobrobytu $(0,65)$. Cechuje się także najniższym zróżnicowaniem w osiaganych wynikach (wariancja z próby 0,01$)$. Model uzyskał najwyższe wyniki we wszystkich kategoriach, za wyjątkiem skolaryzacji i PKB per capita. W dodatku, wskaźnik innowacyjności i dochodu rozporządzalnego znacząco przewyższa poziom wskaźników w pozostałych modelach. Najniższe zróżnicowanie dotyczy wskaźników: PKB per capita $(0,002)$, oczekiwana długość życia $(0,005)$ i dochód rozporządzalny gospodarstw domowych $(0,009)$. W pozostałych wskaźnikach wyróżnia się Szwecja (zatrudnienie i innowacyjność) oraz Austria i Finlandia (skolaryzacja).

Indeks Dobrobytu modelu „administracyjno-socjalnego” nieznacznie przewyższył poziom indeksu modelu „możliwości rozwojowych” (0,39). Jego cechą charakterystyczną jest najwyższy poziom zróżnicowania państw (w grupie państw śródziemnomorskich i postsocjalistycznych znalazł się Luksemburg, osiagający najwyższy poziom w całej badanej grupie pod względem PKB per capita i dochodu rozporządzalnego). Model wyróżnia się najniższym wskaźnikiem zatrudnienia i stosunkowo niskim poziomem wskaźnika skolaryzacji (jedynie Grecja uzyskała najwyższy wśród wszystkich państw wskaźnik) i innowacyjności. Atutem państw wchodzących do modelu jest długość życia (za wyjątkiem Polski i Luksemburga). 
RYSUNEK 6

Wskaźniki Indeksu Dobrobytu w krajach zaklasyfikowanych do modelu „administracyjno-socjalnego"

$\longrightarrow$ PKB per capita

zatrudnienie

skolaryzacja

długość życia

patenty

dochód rozporządzalny

Źródło: opracowanie własne.

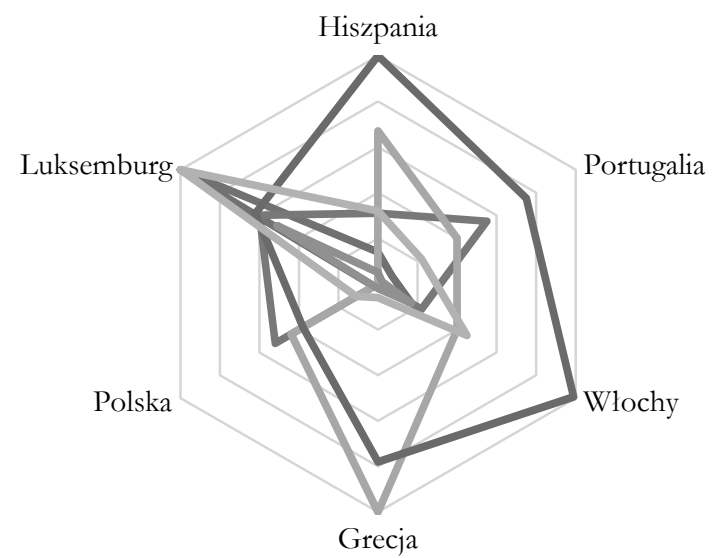

RYSUNEK 7

Wskaźniki Indeksu Dobrobytu w krajach zaklasyfikowanych do modelu „liberalnego”

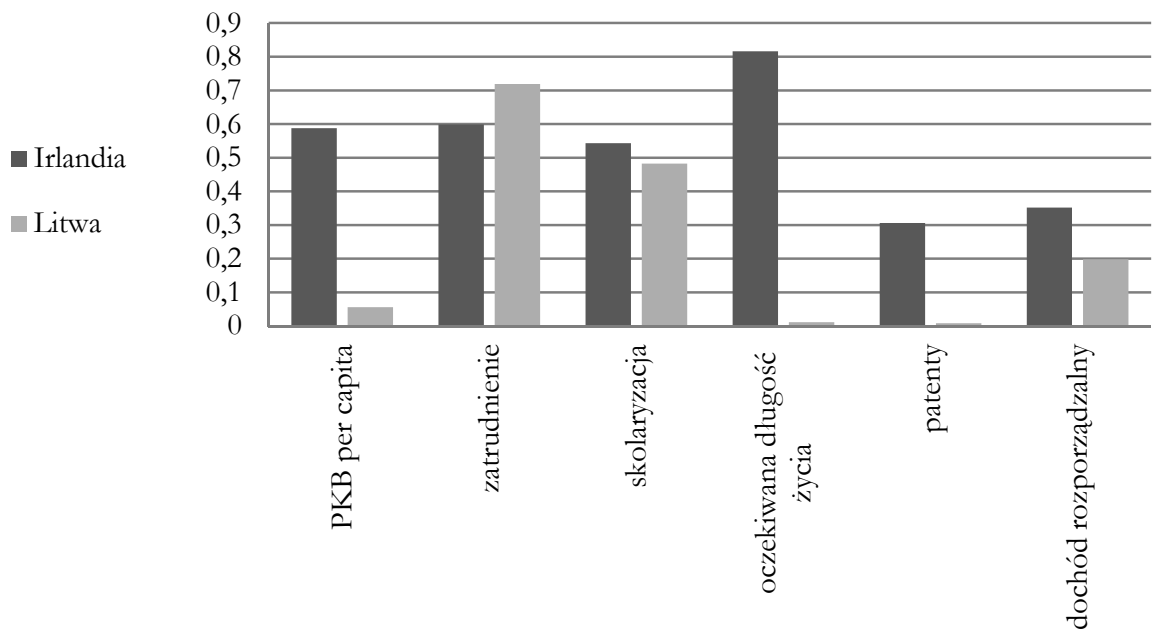

Źródło: opracowanie własne. 
Do modelu „liberalnego” zaklasyfikowano jedynie dwa państwa: Irlandię i Litwę. Indeks Dobrobytu tego modelu znajduje się na tym samym poziomie co modelu „administracyjno-socjalnego” (0,39). Również zróżnicowanie wyników państw zaliczonych do obu modeli jest na tym samym poziomie $(0,09)$. Odznacza się najwyższym, wśród pozostałych modeli, wskaźnikiem PKB per capita $(0,32)$ i stosunkowo wysokim wskaźnikiem skolaryzacji $(0,51)$. Jednakże niskie noty uzyskał w pozostałych składowych Indeksów: wyprzedza jedynie model „możliwości rozwojowych" we wskaźnikach: oczekiwana długość życia i dochód rozporządzalny gospodarstw domowych, a model ,administracyjno-socjalny” we wskaźniku zatrudnienie i liczba patentów. W modelu wiedzie prym Irlandia - Litwa osiagnęła wyższy poziom jedynie wskaźnika zatrudnienie.

\section{Podsumowanie}

Na potrzeby badania wyłoniono cztery grupy wydatków, odpowiadające czterem głównym koncepcjom z zakresu interwencji państwa i sposobów kształtowania dobrobytu społeczeństwa: wydatki klasyczne (podstawowe funkcje państwa wg ekonomii klasycznej), wydatki na sprawy gospodarcze (interwencjonistyczne koncepcje dobrobytu), wydatki na cel ,inwestycje w kapitał ludzki” (teoria dobrobytu jako zespołu możliwości A. Sena), ochrona socjalna (funkcja dobrobytu maxmin). $\mathrm{Na}$ podstawie udziałów w strukturze wydatków publicznych wymienionych powyżej kategorii wyłoniono, przy pomocy analizy skupien, pięć modeli fiskalizmu, jednocześnie będących wyrazem przyjętej koncepcji dobrobytu ogólnego. Są to: model „możliwości rozwojowych” (teoria możliwości A. Sena i interwencjonistyczne koncepcje dobrobytu), model ,zrównoważonego wsparcia” (funkcja dobrobytu maxmin i teoria A. Sena), model „ochrony socjalnej” (dochodowe podejście do dobrobytu, funkcja maxmin) oraz model ,administracyjno-socjalny” (dochodowa koncepcja dobrobytu, funkcja maxmin) i model „liberalny” („teoria możliwości” A. Sena).

W grupie państw charakteryzujących się wysokim udziałem wydatków inwestycje w kapitał ludzki znajdują się kraje zaliczone do dwóch modeli fiskalnych: „możliwości rozwojowych”(Australia, Lotwa, Czechy, Węgry) i „liberalnego” (Irlandia i Litwa). Analiza Indeksu Dobrobytu i jego poszczególnych wskaźników wykazała jednak, że cechują się one niskim poziomem dobrobytu, a pomimo zwiększonego wsparcia takich obszarów, jak: edukacja, zdrowie etc. wskaźniki długości życia czy innowacyjności są na bardzo niskim poziomie. Założenie wspierania edukacji obywateli w celu zwiększenia przyszłych dochodów również nie jest odzwierciedlone w poziomie wskaźnika dochodu rozporządzalnego. Jedynie wskaźnik skolaryzacja wyróżnia się na tle pozostałych modeli, a w przypadku modelu „liberalnego” wskaźnik PKB per capita. W modelu „możliwości rozwojowych” stymulacja gospodarki nie przełożyła się na wysokość wskaźnika produktu per capita (najniższy poziom wśród modeli).

Ochrona socjalna jest priorytetowym obszarem aktywności w dwóch modelach fiskalnych: „ochrony socjalnej” i „administracyjno-socjalnego”. Modele różnią się 
wysokością udziału wydatków klasycznych w strukturze wydatków. O ile model „ochrony socjalnej” uzyskał najwyższy poziom Indeksu Dobrobytu, model „administracyjno-socjalny" jedynie w niewielkim stopniu prześcignął model o najsłabszych wynikach. Model uzyskał względnie wysoki poziom wskaźnika oczekiwana długość życia, dochód rozporządzalny gospodarstw domowych i PKB per capita (za sprawą ujęcia w modelu Luksemburga). Najniższy udział wydatków ,inwestycje w kapitał ludzki" przełożył się na najsłabszy wynik wśród modeli we wskaźniku zatrudnienie i skolaryzacja. Z kolei model „ochrony socjalnej” uzyskał nie tylko najwyższy Indeks Dobrobytu, ale cechuje się on również najniższym zróżnicowaniem struktury wydatków publicznych i poszczególnych wskaźników dobrobytu. Jedynie w składowych dobrobytu: skolaryzacja i PKB per capita osiagnął nieznacznie niższy wynik od najwyższego poziomu pozostałych modeli.

Z kolei model „zrównoważonego wsparcia”, jak sama nazwa wskazuje, cechuje się zbliżoną wysokością udziałów wydatków ,inwestycje w kapitał ludzki’ i „ochrony socjalnej”. Również w kategorii wydatków wspierających gospodarkę i wydatków klasycznych przyjmuje wartość średnią dla wszystkich modeli. Pod względem poziomu Indeksu Dobrobytu model ten uplasował się na drugiej pozycji za modelem „ochrony socjalnej”, także pod względem zróżnicowania wyników zaklasyfikowanych do niego państw. Jednakże należy zauważyć, że najniższe noty otrzymał w kategorii PKB per capita, skolaryzacja, oczekiwana długość życia. Jego atutem jest stosunkowo wysoka innowacyjność, zatrudnienie i poziom dochodów.

Badanie wyłoniło kolejne pytania badawcze w zakresie zasadności zwiększania wydatków wspierających gospodarkę i konieczności ograniczania kosztów funkcjonowania administracji. Modele bazujące na koncepcji dochodowej dobrobytu osiagnęły wyższy poziom Indeksu Dobrobytu niż modele oparte na teorii możliwości rozwojowych Sen'a. Biorąc pod uwagę poszczególne wskaźniki, modele fiskalizmu stymulujące dobrobyt bezpośrednimi strumieniami pieniężnymi w formie świadczeń socjalnych osiagnęły wyższe wyniki pod względem poziomu dochodu rozporządzalnego i oczekiwanej długości życia, a modele wspierające obszar dobrobytu niematerialnego - skolaryzacji. Można wysunąć wnioski o potrzebie działań sięgających zarówno do dochodowych koncepcji dobrobytu, jak i teorii możliwości rozwojowych A. Sena. Oznacza to stworzenie równych wszystkim obywatelom szans rozwojowych na skutek silnego zaplecza instytucjonalnego ochrony zdrowia, środowiska czy edukacji, wzmocnionych przy pomocy bezpośrednich strumieni finansowych, kierowanych do obywateli. Jednakże przy formułowaniu tego typu wniosków należy pamiętać o stopniu rozwoju gospodarek wchodzących w skład modeli fiskalnych i ich uwarunkowaniach historyczno-kulturowych. W celu weryfikacji tych założeń należałoby także przeprowadzić szersze badania, uwzględniające dane z długiego okresu obserwacji. 


\section{Literatura}

Abrams B., 1999, The Effect of Government Size on the Unemployment Rate, Public Choice 99 (3-4), [za:] N'Guessan C.F.J., 2017, Threshold Effect of Government Consumption on Employment: Evidence form African Countries, "Journal of Economics and Development Studies", vol. 5(2), DOI: 10,15640/jeds.v5n1a2.

Aksman E., 2010, Redystrybucja dochodów i jej wptyw na dobrobyt spoleczny w Polsce w latach 1995-2007, Wydawnictwo Uniwersytetu Warszawskiego, Warszawa.

Alesina A., Ardagna S., Perotti R., Schiantarelli F., 1999, Fiscal Policy, Profits, and Investment, "National Bureau of Economic Research Working Paper”, no. 7207, [za:] Loizides J., Vamvoukas G., 2005, Government expenditure and economic growth: evidence from trivariate causality testing, "Journal of Applied Economics", vol. 8(1), https://ageconsearch.umn.edu/bitstream/37515/2/loizides.pdf [data wejścia: 13.12.2018].

Atkinson A.B., Brandolini A., 2014, Unveiling the Ethics behind Inequality Measurement: Dalton's Contribution to Economics, Nuffield College, Oxford and London School of Economics, DOI: 10.1111/ecoj.12225.

Biernacki M., 2006, Kilka uwag o pomiarze dobrobytu spolecznego, „Mathematical Economics", nr 3(10), https://journal.ue.wroc.pl/index.php?id=show_article $\& n=113 \& c z=1$ [data wejścia: 02.05.2017].

Dąbrowa M., 2011, Badanie poziomu życia - metodologia konstrukcji wybranych wskaźników, „Zeszyty Naukowe Małopolskiej Wyższej Szkoły Ekonomicznej w Tarnowie”, nr 1(17), http://zn.mwse.edu.pl/ebooki/17/67-82.pdf [data wejścia: 01.05.2017].

Fender V., Haynes J., Jones R., 2011, Measurign Economic Well - being, Office for National Statistic, London.

Fölster S., Henrekson M., 1999, Growth and the Public Sector: A Critique of the Critics, "European Journal of Political Economy", vol. 15(2), https://swopec.hhs.se/ iuiwop/papers/iuiwop0492.rev.pdf [data wejścia: 11.12.2018].

Fölster S., Henrekson M., 2001, Growth Effects of Government Expenditure and Taxation in Rich Countries, "European Economic Review", vol. 45(8), DOI: 10.1016/ S0014-2921(00)00083-0.

Fuente A., Jimeno J.F., 2005, The private and fiscal returns to schooling and the effect of public policies on private incentives to invest in education: a general framework and some results for the EU, CESifo Working Paper, [za:] European Commision, Efficiency and effectiveness of public expenditure on ter tiary education in the UE, http://ec.europa.eu/ economy_finance/publications/occasional_paper/2010/pdf/ocp70_en.pdf [data wejścia: 13.12.2018]

Jackson T., 2015, Dobrobyt bez wrrostu. Ekonomia dla planety o ograniczonych możliwościach, Wydawnictwo Naukowe Uniwersytetu Mikołaja Kopernika, Toruń.

Karras G., 1996, The Optimal Government Size: Further International Evidence on the Productivity of Government Services, "Economic Inquiry”, vol. 34(2), DOI: 10.1111/ j.1465-7295.1996.tb01372.x. 
Machowska-Okrój S., 2013, W Zrost gospodarçy a dobrobyt w Polsce i krajach ósiennych, [w:] Ekonomiczne nyz̧wania wspótczesności, Kuczewska J., Stefaniak-Kopoboru J., Krzemiński M. (red.), Fundacja Rozwoju Uniwersytetu Gdańskiego, Sopot.

Mitchell D.J., 2005, The Impact of Government Spending on Economic Growth, „Executive Summary Backgrounder The Heritage Foundation”, no. 1831, DOI: 10.1080/ 10430719008404677.

Novignon J., Olakojo S.A., Nonvignon J., 2012, The effect of public and private health care expenditure on health status in sub-Saharan Africa: new evidence from panel data analysis, DOI: $10.1186 \% 2 F 2191-1991-2-22$.

OECD, 2011, Government at a glance 2011, Załącznik B, https://www.oecd.org/ gov/48250728.pdf [data wejścia: 18.11.2017]

Paternostro S., Rajaram A., Tiongson E.R., 2007, How Does the Composition of Public Spending Matter?, “Oxford Development Studies”, vol. 35(1), http://www1. worldbank.org/publicsector/pe/pfma07/CompositionSpending.pdf [data wejścia: 11.12 .2018$]$.

Peden A.E., 1991, Productivity in the United States and Its Relationship to Government Activity: An Analysis of 57 Years, 1929-1986, "Public Choice", vol. 69, [za:] Park H., 2006, Expenditure Composition and Distortionary Tax for Equitable Economic Growth, IMF Working Paper WP/06/165, DOI: 10.5089/9781451864250.001.

Szopa B., 2012, Główne myznaczniki bogactwa i zamožności, [w:] Wokót ragadnień ubóstwa i bogactwa, Szopa B. (red.), Wydawnictwo Uniwersytetu Ekonomicznego w Krakowie, Kraków.

Tanzi V., Shuknecht L., 1996, Reforming Government in Industrial Countries, International Monetary Fund Finance \& Development, www.imf.org/external/pubs/ $\mathrm{ft} /$ fandd/1996/09/pdf/tanzi.pdf [data wejścia: 11.12.2018].

Veugelers R., van der Ploeg F., 2008, Towards Evidence-based Reform of European Universities, "CESifo Economic Studies", vol. 54(2), DOI: 10.1093/cesifo/ifn015.

www 1, https://data.oecd.org/healthstat/life-expectancy-at-birth.htm [data wejścia: 25.10.2018].

www 2, http://data.uis.unesco.org/index.aspx?queryid=142 [data wejścia: 25.10. 2018].

www 3, https://data.oecd.org/rd/triadic-patent-families.htm [data wejścia: 25.10. 2018].

www 4, https://data.oecd.org/hha/household-disposable-income.htm [data wejścia: 25.10.2018].

www 5, https://data.oecd.org/emp/employment-rate.htm [data wejścia: 25.10. 2018]. 